\title{
Cutting Edge of Reproductive Medicine
}

\author{
Budi Wiweko \\ President of ASPIRE (Asia Pacific Initiative on Reproduction) \\ Vice Director Indonesian Medical Education Research Institute (IMERI) \\ Faculty of Medicine Universitas Indonesia - Dr. Cipto Mangunkusumo General Hospital \\ Jakarta - Indonesia
}

\begin{abstract}
Background: Louise Brown's delivery in 1978 was the mark of a successful IVF program that has now been in practice for more than 40 years. The technology has delivered more than 8 million babies. Many breakthrough innovations were established to answer the problem in ART services. Optimizing ART biomarkers and cross border reproductive care have become a rising issue in ART services. Disruptive innovation disrupts the existing condition and takes the lead in the new market, including to change our patient behavior in health services. National health services addressed new issues about the impact of 4.0 industrial revolution on health workforce and our daily practices. Every disruptive innovation today is enhanced by a combination of physical, digital, and biological domain. The advancement in the area of the internet of things, artificial intelligence, virtual reality, nanotechnology, cloud computing, big data, deep learning, machine learning, robotics, and gene editing could potentially support us to innovate. And to improve the quality and outcome of ART, the introduction of the latest technology, such as robotics and artificial intelligence, has become an essential approach. A recent study discovered that the use of artificial intelligence would remove the embryologist's subjectivity and improve the way we choose the best embryo for implantation. The next challenging issue in ART is improving the success rate through optimizing noninvasive biomarkers development. Many biological products such as blood, tissue, organ fluid can be assessed and considered to be used as IVF biomarkers. Proteomic tools were used and are needed to analyze a sample from subjects before it was created as a biomarker for improving the IVF services quality.

Conclusion: The development of IVF over 40 years has brought about many distinct achievements in the laboratory and in clinic. Industrial revolution 4.0 has generated many innovations that have helped improve the quality of ART services, including AUGMENT social egg freezing, artificial intelligence, and genome editing. In this era, precision medicine looks very promising for bridging the gap and increasing the accuracy and efficacy of promotive, preventive, diagnostic, and treatment approaches in reproductive medicine.
\end{abstract}

Keywords: Cutting Edge; Big Data; BioInformatics; Reproductive Medicine; Artificial Intelligence In Vitro Fertilization; IVF.

\section{ABSTRAK}

(ABSTRACT IN INDONESIAN)

Latar Belakang: Lahirnya Louise Brown pada tahun 1978, menandakan awal dari keberhasilan program bayi tabung yang telah berlangsung lebih dari 40 tahun hingga sekarang. Teknologi ini telah membantu menghasilkan lebih dari 8 juta bayi. Banyak inovasi baru yang telah ditemukan untuk menyempurnakan dan meningkatkan pelayanan teknologi reproduksi berbantu (TRB). Mengoptimalkan biomarker pada TRB dan pelayanan reproduksi antar negara menjadi topik hangat yang dibicarakan seputar pelayanan TRB. Inovasi disruptif dapat merubah situasi pasar sekaligus memimpin pasar hingga merubah sikap pasien terhadap pelayanan kesehatan reproduksi. National heart services (NHS) mengemukakan tentang bagaimana industri revolusi 4.0 merubah dunia kesehatan dan juga pelayanan kesehatan sehari-hari. Setiap inovasi disruptif yang ada saat ini diciptakan dengan kombinasi dari fisik, digital dan biologis. Peningkatan dan penggunaan internet, kecerdasan buatan, realita virtual, nanoteknologi, cloud computing, big data, deep learning, machine learning, robotik dan gene-editing dapat membantu kita untuk menemukan penemuan baru serta menyempurnakan kualitas dan luaran dari TRB. Penemuan terakhir seperti penggunaan robot serta kecerdasan buatan, menjadi pijakan penting untuk kemajuan pelayanan TRB, studi terakhir menemukan bahwa penggunaan kecerdasan buatan akan mengurangi subjektivitas seorang embriologis dalam memilih embrio, sehingga dapat diperolehnya embrio terbaik untuk implantasi. Kedepannya isu yang menarik dalam pelayanan TRB adalah penggunaan dan pengembangan biomarker non-invasif

(c) 2019 by the Asia Pacific Initiative on Reproduction (ASPIRE) and World Scientific Publishing Co. Pte. Ltd. O Open Access article under the CC BY-NC-ND license (http://creativecommons.org/licenses/by-nc-nd/4.0/).

Received 3 June 2019; Accepted 5 June 2019; Published 1 July 2019

Correspondence should be addressed to: Dr. Budi Wiweko, Asian Pacific Initiative on Reproduction, Indonesian Medical Research Institute, Faculty of Medicine, University of Indonesia, Dr. Cipto Mangunkusumo General Hospital Jakarta, No. VI, Jl. Salemba Raya No. 5, RW. 5, Kenari, Kec. Senen, Kota Jakarta Pusat, DKI Jakarta 10430, Indonesia. Email: budiwiweko@gmail.com 
untuk meningkatkan tingkat keberhasilan pelayanan TRB. Produk biologis seperti darah, jaringan, cairan organ, dapat digunakan dan dipertimbangkan untuk menjadi biomarker baru pada pelayanan TRB. Alat proteomika sudah digunakan terlebih dahulu untuk menganalisa sampel dari subjek, sebelum dibentuk menjadi sebuah biomarker untuk meningkat kualitas pelayanan TRB.

Kesimpulan: Empat puluh tahun pengembangan teknologi reproduksi berbantu (TRB) telah menghadirkan banyak penemuan baru secara laboratoris dan klinis, serta revolusi industri 4.0 memacu kita untuk menemukan inovasi baru pada TRB seperti penggunaan Autologous Germline Mitochondrial Energy Transfer (AUGMENT), social egg freezing, kecerdasan buatan, dan penyuntingan genom. Pada era ini, precision medicine terlihat sangat menjanjikan untuk mengejar ketertinggalan dan untuk meningkatkan akurasi serta efikasi dalam tindakan promosi, preventif, diagnostik dan tatalaksana pada kesehatan reproduksi.

Kata Kunci: Teknologi Reproduksi Berbantu; Trobosan baru; Big Data; Bioinformatika; Kesehatan Reproduksi; Fertilisasi in Vitro; Kecerdasan buatan pada Fertilisasi In Vitro.

\section{INTRODUCTION}

Louise Brown's delivery in 1978 was the start of a successful IVF program that has been in practice for more than 40 years. The technology has delivered more than 8 million babies. The development of IVF has fundamentally given the possibility for every couple to achieve their dreams of having children.

Many breakthrough innovations were established to solve the problems in ART services. Optimizing ART biomarkers, and cross border reproductive care has become a rising issue in ART services. In the era of 4.0 industrial revolution, there is a large amount of big data available, precision reproductive medicine, and artificial intelligence technology to improve the quality of ART services as shown in Fig. 1 (Niederberger et al., 2018).
Every disruptive innovation today is enhanced by a combination of physical, digital, and biological domain. The advancement in the area of the internet, artificial intelligence, virtual reality, nanotechnology, cloud computing, big data, deep learning, machine learning, robotics, and gene editing could all potentially support us in innovations (Fig. 2).

Disruptive innovation disrupts the existing condition and takes the lead in the new market, including to change our behavior in health services. National health services addressed new issues about the impact of 4.0 industrial revolution on the health workforce and on our daily practices (Topol, 1998).

Competencies in reading the genome are critical given the most substantial impact to current health services and workforce

Fig. 1. How to improve the quality of ART services (Wiweko et al., 2019).

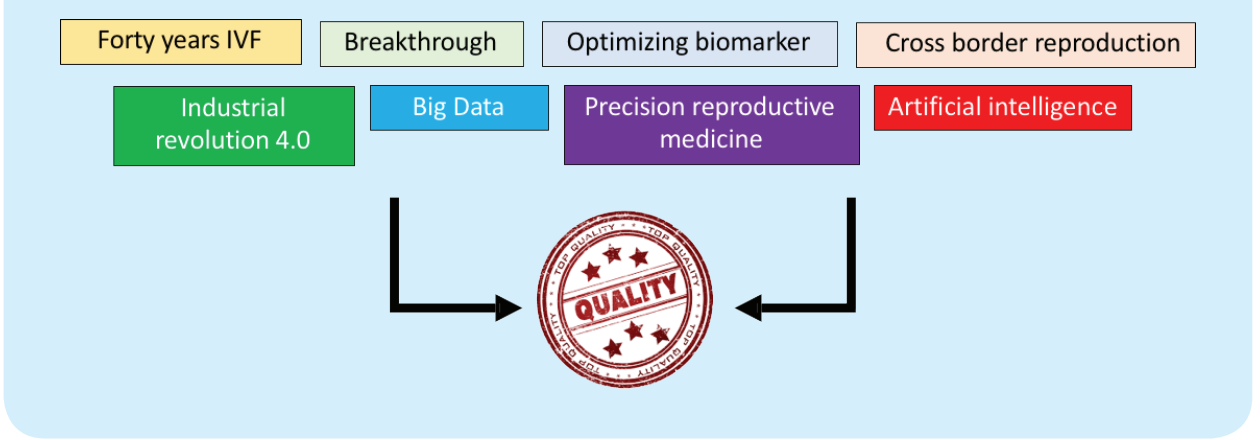

Fig. 2. Technology disruption era and 4.0 Industrial Revolution (Kemristek-Dikti, 2018).

\section{Challenge \\ INDUSTRIAL REVOLUTION 4.0 \& Digital Economy}

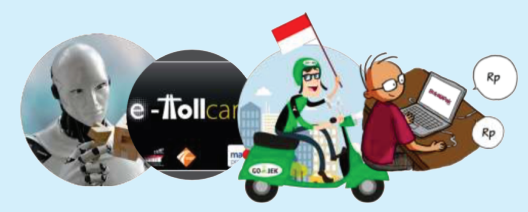

$$
\begin{gathered}
\text { 75-375 Million } \\
\text { GLOBAL } \\
\text { EMPLOYEES SHIFT } \\
\text { PROFESSIONS }
\end{gathered}
$$

Technology disruption era is the combination of physical, digital and biological domain (Schwab, 2017)
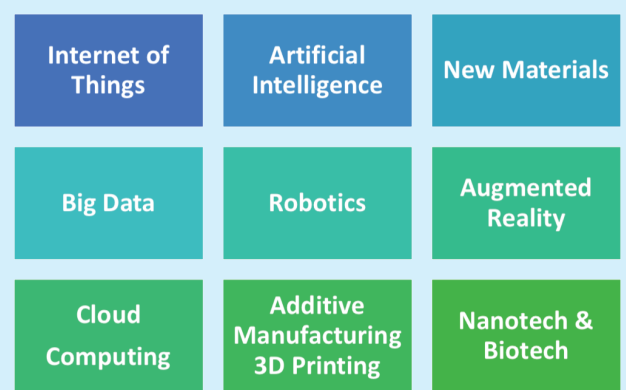

Nanotech \& Biotech

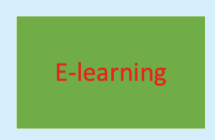


Fig. 3. Technological advances impacting healthcare and the magnitude of disruption. Adapted from Topol (2019).

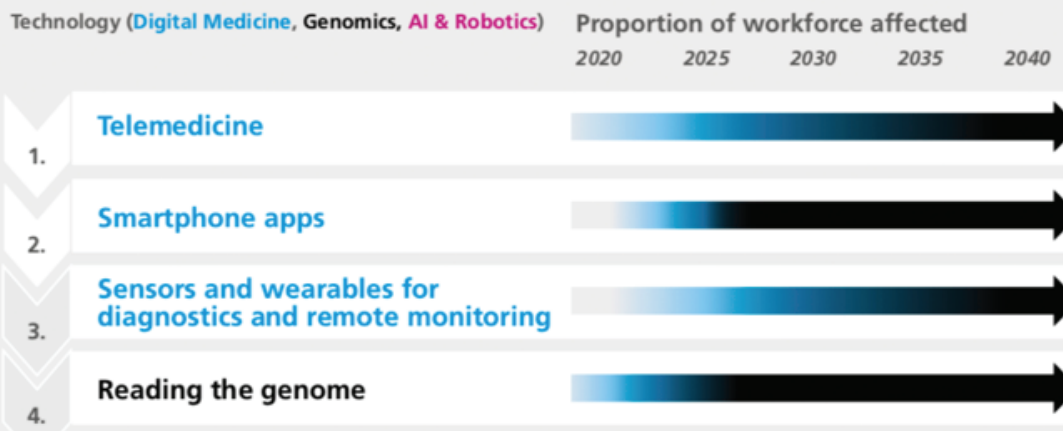

4.

Speech recognition and natural

language processing (NLP)

6.

Virtual and augmented reality

Automated image

interpretation using Al

Interventional and

rehabilitative robotics

Predictive analytics using Al

Writing the genome

10.

Arrow heat map represents the percerved magnitude of

impact on current models of care and, by inference, or

the proportion of workforce affected

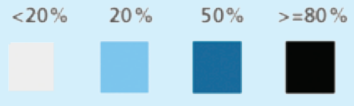

(up to more than $80 \%$ ), followed by smartphone apps, speech recognition, predictive analytics using artificial intelligence and wearable sensor diagnostic devices (Topol, 1998) (Fig. 3).

\section{UNLOCKING HEALTH CARE BY BIG DATA}

Digital revolution is leading health care through exploding amounts of various data which include clinical and genomics. In the current situation, the clinical phenotype can be described more quantitatively and biochemically using big data. We can retrieve big data (Fig. 4) through hospital electronic health records, including all data from outpatients, inpatients, operating theatres, laboratories, and biobanks. An integrative analysis of heterogeneous data consists of genomics, proteomics, transcriptomics, epigenomics, metabolomics, biomedical data, as well as electronic health records (Issa et al., 2014; Ristevski and Chen, 2018).

In the big data era, bioinformatics is the knowledge of computational tools for comprehensive analysis. This knowledge accurately identifies which molecular target to use for early clinical diagnosis and intervention. The most important part is to understand the interaction between genetic, epigenetic, environment, and lifestyle to emphasize deep insight into early diagnosis and prevention of the diseases. This concept is acknowledged as precision medicine (Ristevski and Chen, 2018) (Fig. 5).

While IVF is in the era of precision medicine, only $5 \%$ of fresh oocytes produce a baby, reflecting high biological inefficiency.
To increase the success rates, we need to optimize biomarker for detecting functional oocyte, good sperm, good embryo, and receptive endometrium by the combination of all related clinical data and potential expressed genes (Simón and Giudice, 2017).

IVI group from Valencia has succeeded in producing a commercially available endometrial receptivity array (ERA) which utilizes 238 related expressed genes in the endometrium to precisely predict the window of implantation of women who join the IVF program (Fig. 6). This kind of method has been studied to see their consistency and low inter- and intra-observer variability as compared to the pathologist (Ruiz-Alonso et al., 2013).

\section{ROBOTICS AND ARTIFICIAL INTELLIGENCE IN REPRODUCTIVE MEDICINE}

These ideas were started in 2012 when Markus Maseguer from IVI Valencia published his opinion regarding full roboticsassisted reproductive technology laboratory. Working in the IVF laboratory requires a passionate person, as the work entails a delicate and complicated process as well as a significant amount of responsibilities, and no mistake will be tolerated during the procedures.

To improve the quality and outcome of ART, the introduction of the latest technology, such as robotics and artificial intelligence, has become an essential approach. The microfluidic technique allows us to establish an automated cell culture device and control how the 
Fig. 4. Components of big data along with the actions that can be taken with big data. Adapted from Issa et al. (2014).

Laboratory test findings Mortality and disease registries Drug prescription dispensing Geriatric assessment

Hospital discharge diagnoses

Outpatient diagnostic test

Emergency department visits

record linkage

Clinical databases

Primary care DBs

Biobank

Prospective data collection

Healthcare service payment

Other administrative DBs

Fig. 5. Bioinformatics and their derivatives. Adapted from Ristevski and Chen (2018).

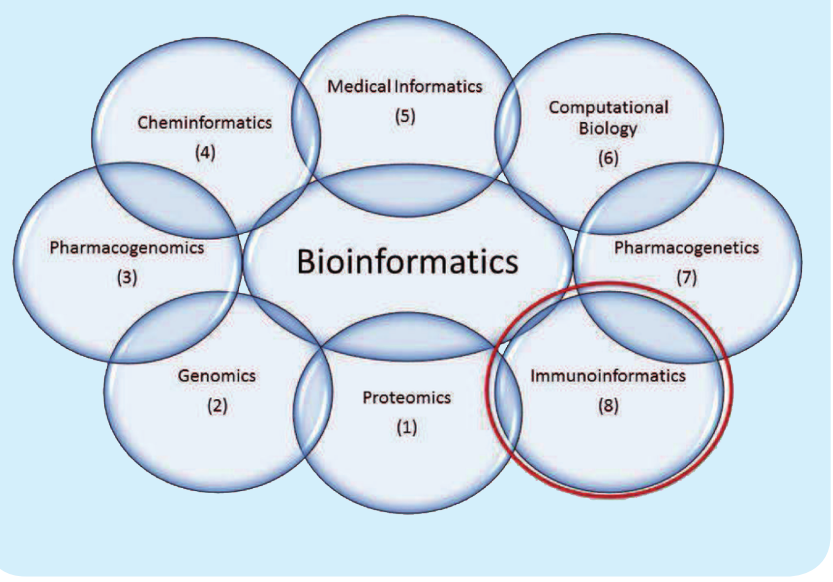

medium fluid is automatically changed. Robotic systems can improve the process of cumulus cell denudation from oocytes; therefore, all advanced technology complimentary to highly skilled embryologist to increase the success rate of IVF (Meseguer et al., 2012) (Fig. 7).

A recent study discovered that the use of artificial intelligence would remove the embryologist's subjectivity and improve the way we choose the best embryo for implantation. By using particular algorithms that come from big data analysis, clinician and embryologist are facilitated to increase the probability of pregnancy (Fig. 8).

\section{DISRUPTIVE INNOVATION CHANGING IVF SERVICES}

The aging ovary becomes a much more challenging issue in ART since older women have an extremely low success rate due to a poor response to stimulation and frequent aneuploidy. This condition is critical in both clinical and social perspectives.
In the prediction of live births, biological age is a more important factor than chronological age. Therefore, women generally prefer to have children soon after marriage, when their biological age is older than their chronological age (Wiweko et al., 2013) (Fig. 9).

In the late 1990s, an American scientist performed cytoplasmic transfer from younger oocytes for a patient of advanced age that yielded a high pregnancy rate. Ever since DNA was found inside mitochondria, the first "three parents" of IVF babies were delivered in the UK several years ago.

Given the challenge, a possible treatment was to introduce autologous mitochondria transfer using AUGMENT (Autologous Germline Mitochondrial Energy Transfer) technique, in which oogonial stem cells, as a source of mitochondria, was injected concurrently with the sperm during ICSI procedure. It was claimed that AUGMENT could rejuvenate ovarian aging successfully (Woods and Tilly, 2015) (Fig. 10).

The well-established vitrification technique introduced the option of the social egg freezing method to stop the female's biological clock. Many studies published high survival rates of oocytes after vitrification, consequently producing live birth rates similar to fresh IVF. Even a private company has offered a financial plan of oocytes freezing for their female employees. These few technologies have changed patients' daily routines (Martinelli et al., 2015) (Fig. 11).

Recently, Chinese scientists announced their success in editing genes of twin babies by CRISPR/Cas9 technique to protect them against HIV infection. However, this advanced technology has raised many ethical issues since many countries have banned or restricted them by legislation and guidelines (Normile, 2018).

New paradigms put the male factor as the first line of essential infertility investigation since sperm abnormalities are responsible for $30 \%$ of the causes of infertility. Instead of sperm counts, DNA fragmentation index plays a vital role in affecting embryo abnormalities resulting in a high probability incidence of miscarriages (Wiweko and Utami, 2017) (Fig. 12). 
Fig. 6. The endometrial receptivity array for diagnosis and personalized embryo transfer as a treatment for patients with repeated implantation failure. Adapted from Ruiz-Alonso et al. (2013).

(A) Clinical outcome of non receptive RIF and control patients that underwent pET

\begin{tabular}{ll}
\hline & Non Receptive \\
\hline No. of patients & 25 \\
No. of previous failed cycle RIF Patients & $5.0 \pm 1.8$ \\
No. of previous failed cycle Control Patients & $0.3 \pm 0.6$ \\
ERA Prediction & \\
$\quad$ Pre-receptive & $21 / 25(84.0)$ \\
$\quad$ Post-receptive & $4 / 25(16.0)$ \\
$2^{\text {nd }}$ ERA at the specified day (P+4;P+6;P+7; LH+9) a & 18 \\
$\quad$ Months between $1^{\text {st }}$ and $2^{\text {nd }}$ ERA & $2.6 \pm 2.8$ \\
$2^{\text {nd }}$ ERA Receptive at the specified day & 15 \\
Patients with pET $^{\text {b }}$ after $2^{\text {nd }}$ RECEPTIVE ERA & 8 \\
Months between 2 $2^{\text {nd }}$ RECEPTIVE ERA and pET & $1.8 \pm 0.7$ \\
Implantation rate using pET & $5 / 13(38.5)$ \\
Pregnancy rate using pET & $4 / 8(50.0)$ \\
Biochemical pregnancies (\%) & $0 / 4(0.0)$ \\
Clinical abortions (\%) & $0 / 4(0.0)$ \\
\hline
\end{tabular}

(B) Principal component analysis with ERA samples

PCA normalized data

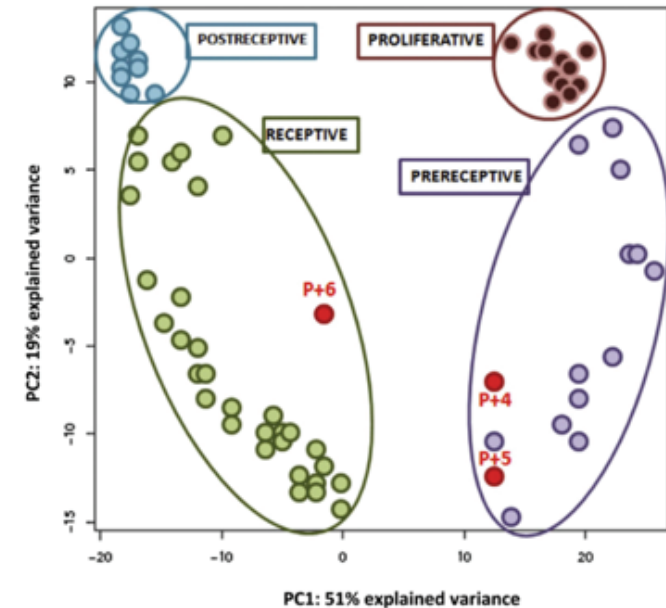

(A) Clinical outcome of nonreceptive RIF and comparison group patients that underwent pET. Values are mean \pm SD. (B) Principal component analysis (PCA) of three samples from the same patient at $\mathrm{P}+4, \mathrm{P}+5$, and $\mathrm{P}+6$, the ERA gene expression training sets (proliferative, pre-receptive, receptive and post-receptive samples) used in the development of the ERA prediction tool (17). The points represent the samples in relation to 238 expressed genes. The three samples from the same patient (at $P+4, P+5$, and $P+6$ ) are represented in red. The samples from the training set are represented in different colors: proliferatives are dark red, pre-receptives are purple, receptives are green, and post-receptives are blue. The study samples $\mathrm{P}+4$ and $\mathrm{P}+5$ show a pre-receptive profile, while the $\mathrm{P}+6$ sample shows a receptive profile. PC1, PC2 = first and second principal components that explain the highest variability that separates samples in the space.

Ruiz-Alonso. Personalized ET in patients with RIF. Fertil Steril 2013.

Fig. 7. Proposed automatic cumulus removal device. Adapted from Meseguer et al. (2012).

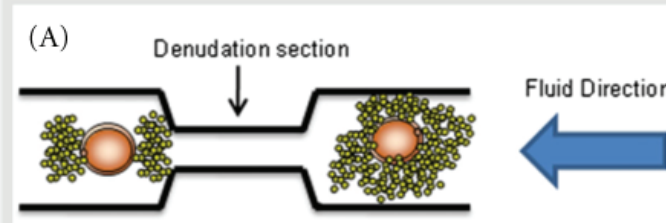

Proposed automatic cumulus removal device ${ }^{7}$

(Zeringe et al.2001).

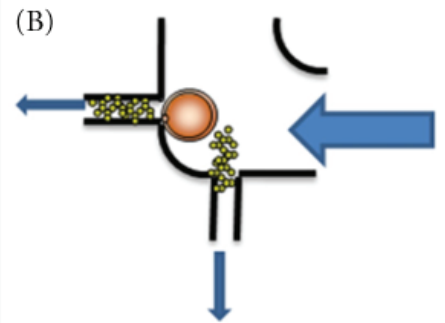

A. The cumulus oocyte complex passes through the narrowed area, emerging with partially removed cumulus cells.

B. By a fluid exposure and a suction force the remaining cumulus cells are stripped from the oocyte.

(C)

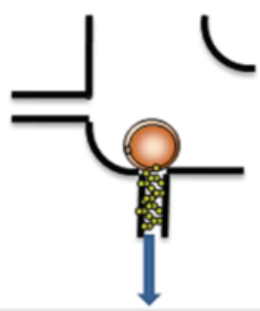

C. The remaining cells are removed in the second removal port when suction is again applied. 
Fig. 8. Artificial Intelligence and IVF. Retrieved from https://www.ivf.com.au/successrates/leading-technology/artificial-intelligence-in-ivf

ARTIFICIAL INTELLIGENCE TOOL FOR PREDICTING THE CHANCE OF A VIABLE PREGNANCY

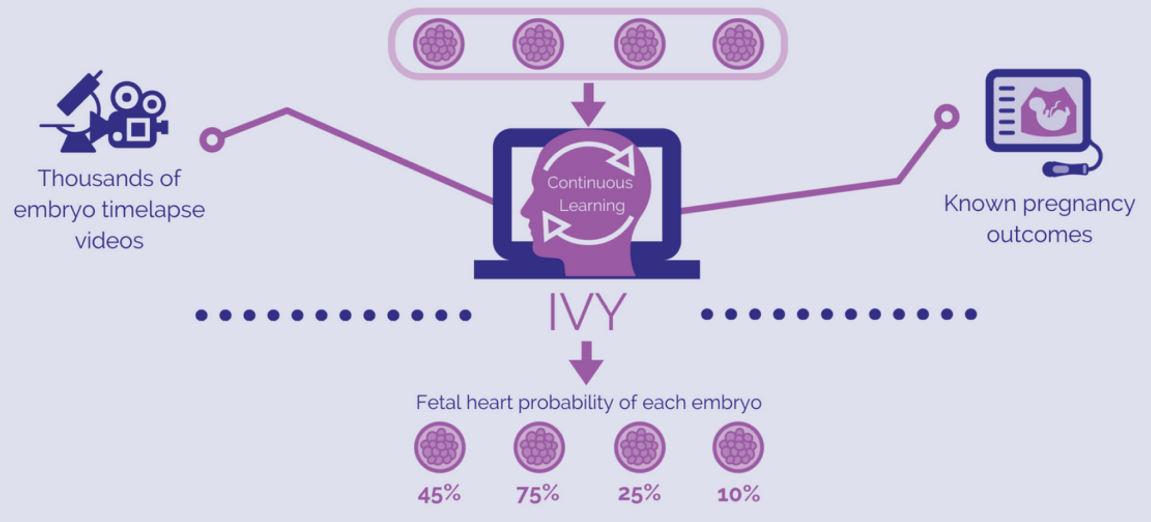

Fig. 9. (A) Frequency of answer regarding reproductive technology decision. (B) Correlation between biological age with tendency of reproductive choices. Adapted from Wiweko et al. (2019).

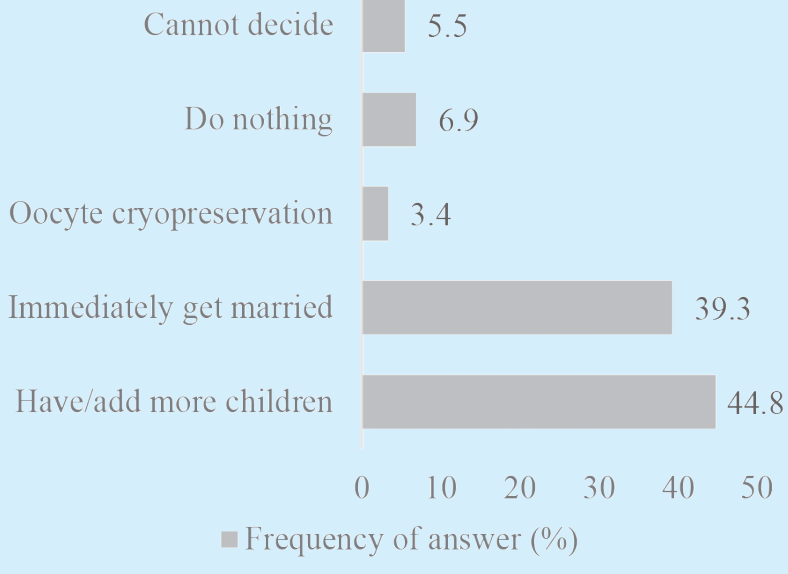

(A)

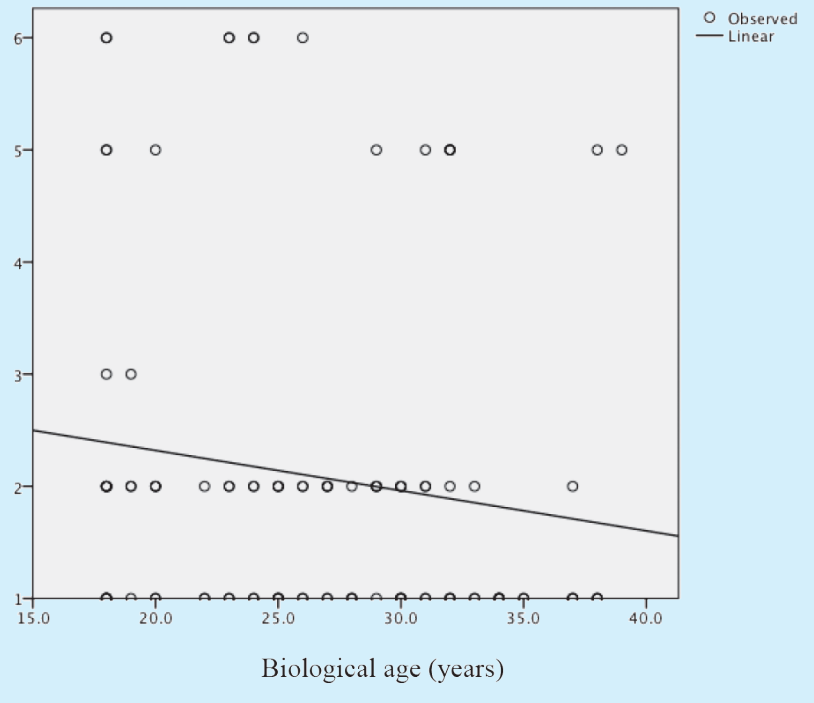

(B)

\section{NONINVASIVE BIOMARKERS IN ART}

The next challenging issue in ART is the improvement of the success rate through optimizing noninvasive biomarker development (Fig. 13). Many biological products such as blood, tissue, and organ fluid can be assessed and considered to be used as IVF biomarkers. Proteomic tools were used and were needed to analyze a sample from subjects before it was created as a biomarker for improving the IVF services quality (Garrido et al., 2013; Upadhyay et al., 2013).

Several developments regarding IVF biomarkers were addressed to focus on improving the prediction of best oocytes, sperm, embryos, and receptive endometrium towards high pregnancy and live birth rates. Micro RNA secreted from endometrium and embryo is one of the potential candidates as a useful biomarker for embryo implantation (Garrido et al., 2013; Rosenbluth et al., 2014; Sanchez et al., 2017) (Fig. 14).

Convergent thinking and transdisciplinary collaboration have become the most critical factors to enable a deeper understanding of biology for solving our societal problems in health, energy, food, and nutrition. We should establish partnerships with our counterparts from the fields of computer science, life science, engineering, and social science, so as to accelerate our achievements in reproductive medicine (National Research Council, 2014). 
Fig. 10. AUGMENT (AUtologous Germline Mitochondrial ENergy Transfer). Adapted from Woods and Tilly (2015).

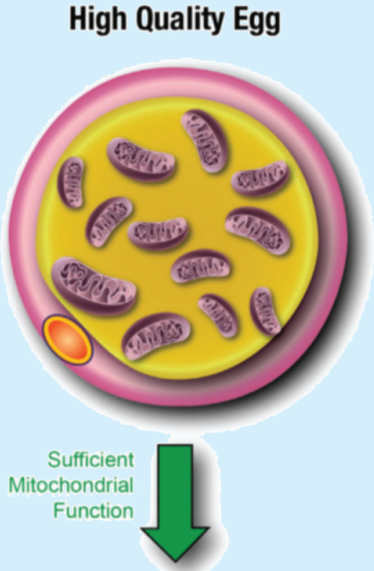

SUCCESSFUL Fertilization and

NORMAL Embryo Development

HEALTHY Pregnancy
Poor Quality Egg

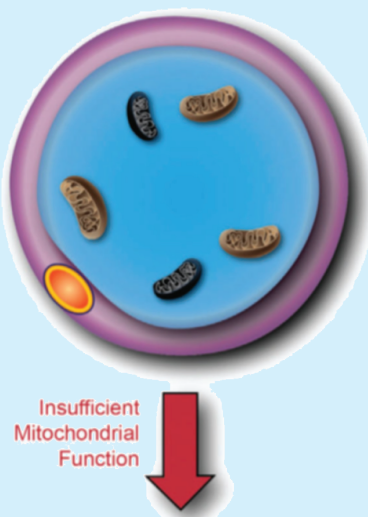

NO Fertilization

POOR Embryo Development

FAILED Pregnancy
Poor Quality Egg

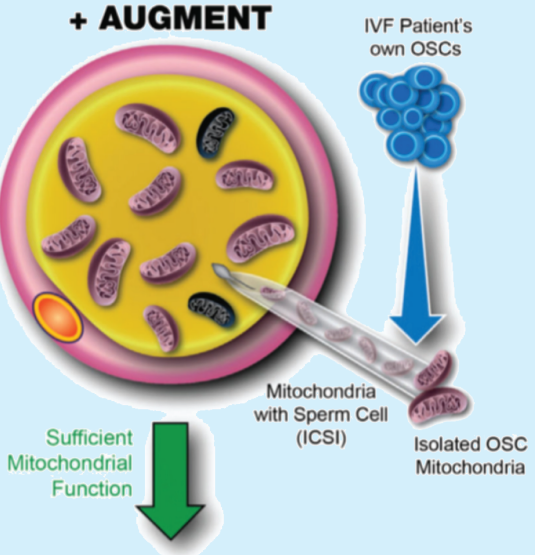

SUCCESSFUL Fertilization and

NORMAL Embryo Development

HEALTHY Pregnancy

Fig. 11. Social egg freezing: A reproductive chance or smoke and mirrors? Retrieved from https://www.eugin.co.uk/egg-vitrification/.

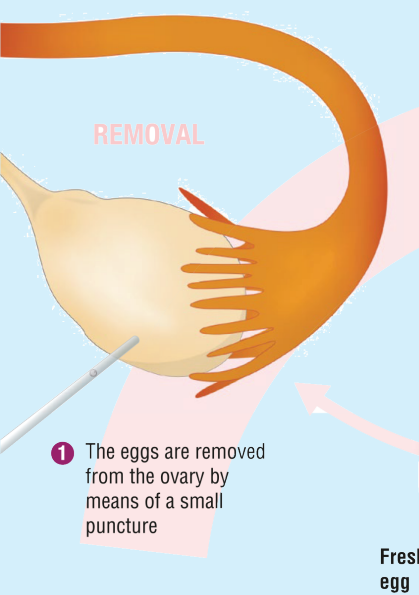

7 To thaw the eggs, the reverse process takes place

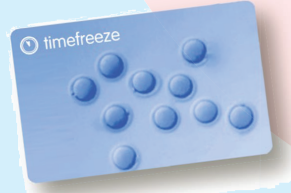

The patient receives a card with the image of the eggs that have been vitrified

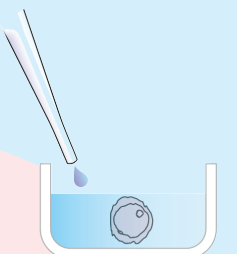

(3) They are bathed in a sucrose solution one by one, which eliminates the water they contain in order to avoid the formation of crystals during freezing, which could damage it
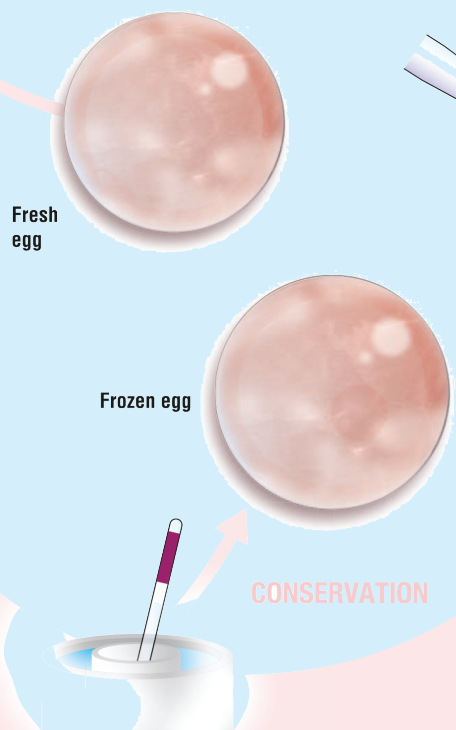

(6) Once frozen, the eggs are kept unaltered in the nitrogen tank indefinitely until use

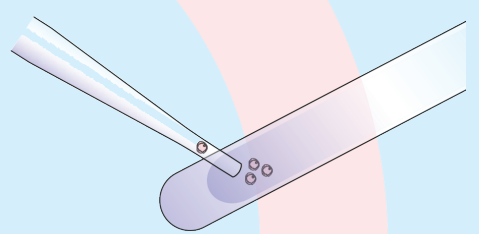

(4) The eggs are placed in a small tube called a straw, ready for cryopreservation

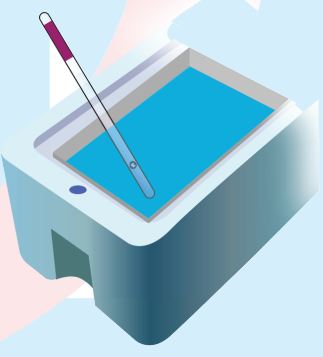

(5) The straws are immersed in liquid nitrogen at -196 degrees, and in a matter of seconds are frozen 
Fig. 12. Predictive value of sperm deoxyribonucleic acid (DNA) fragmentation index in male infertility. Adapted from Wiweko and Utami (2017).
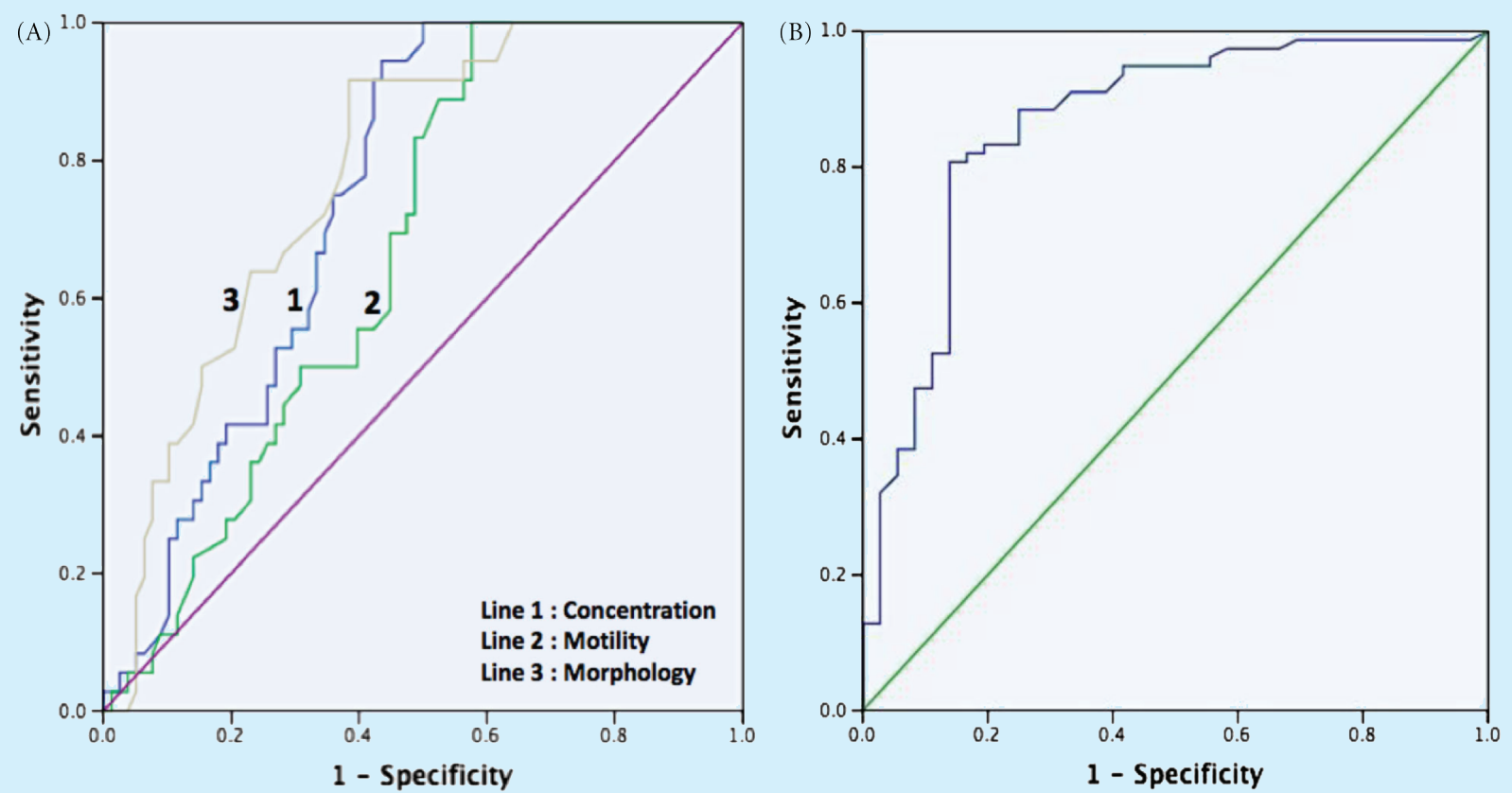

Fig. 1 ROC curve of a semen analysis compared to $\mathbf{b}$ sperm DFI to diagnose male infertility. The three semen parameters: 1) concentration, 2) motility, and 3) morphology have lower AUC compared to sperm DFI

Fig. 13. Schematic representation of various proteomics tools used to study tissues/organs/body fluids in male, female reproductive system and also in embryos. Adapted from Upadhyay et al. (2013).

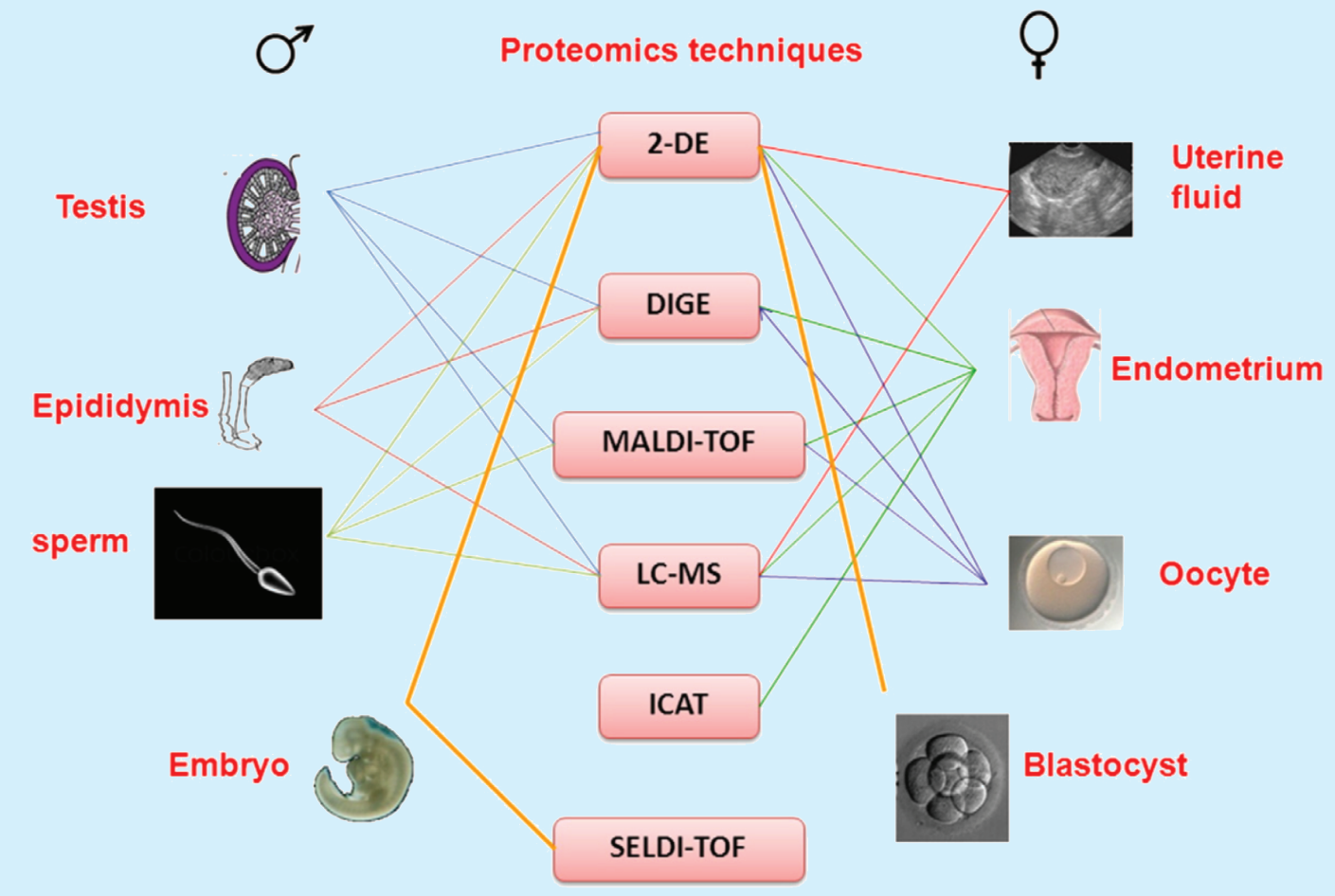


Fig. 14. The number of exclusive and differentially expressed genes according to the mRNA expression profiles of sperm samples achieving pregnancy. Adapted from Garrido et al. (2013).

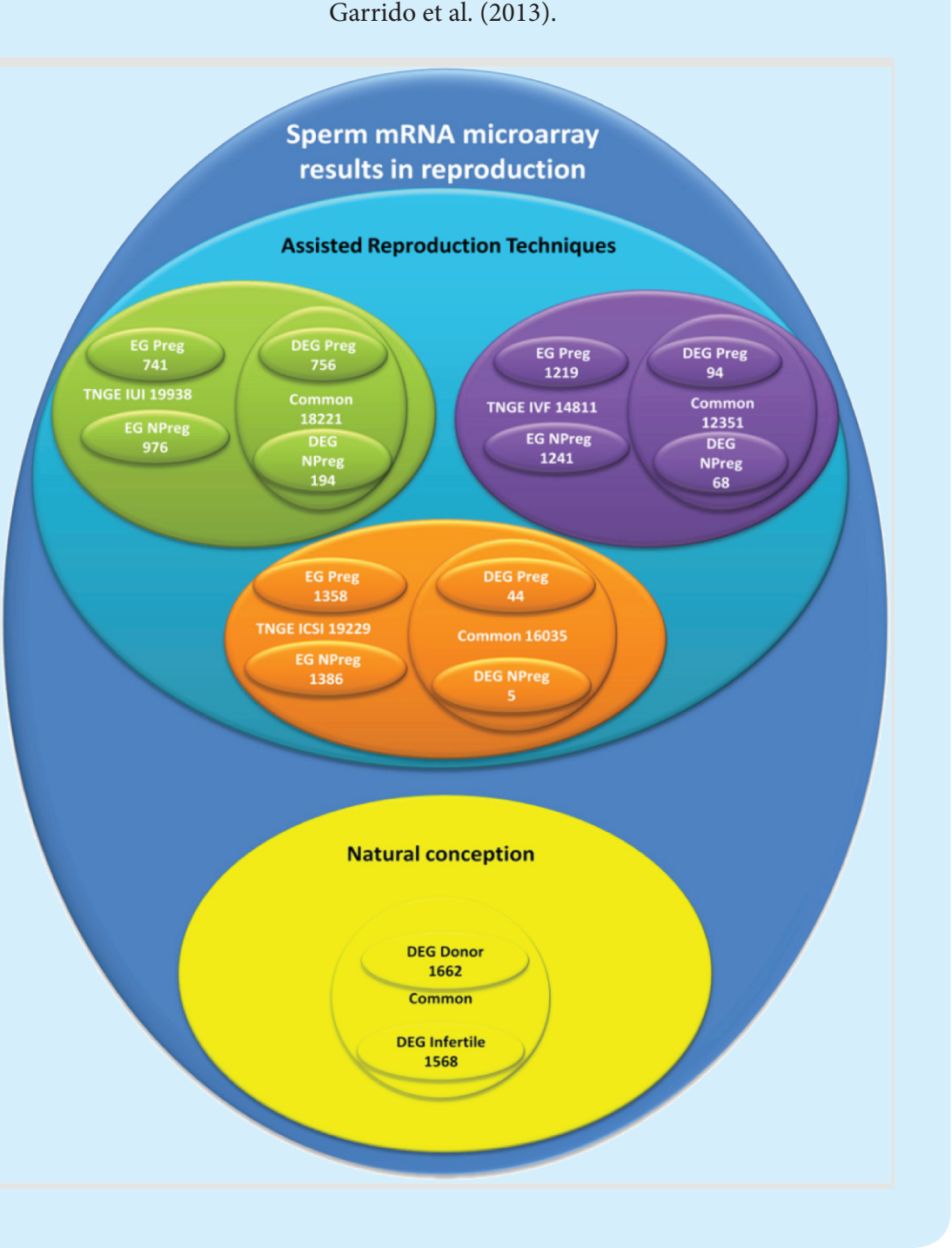

\section{CONCLUSION}

1. The development of IVF over 40 years has brought about many distinct achievements in laboratory and clinical treatment.

2. Industrial revolution 4.0 has generated many cutting-edge innovations including ART services: AUGMENT, social egg freezing, artificial intelligence, and genome editing.

3. Precision medicine holds great promise in bridging the gap and increasing the accuracy and efficacy of promotive, preventive, diagnostic, and treatment approach in reproductive medicine.

4. Time to healthy term singleton delivery becomes an essential consideration for every couple in ART (Bosch et al., 2019).

\section{REFERENCES}

Bosch E, Bulletti C, Copperman AB, Fanchin R, Yarali H, Petta CA, et al. How time to healthy singleton delivery could affect decisionmaking during infertility treatment: a Delphi consensus. Reprod Biomed Online. 2019;38(1):118-30.
Garrido N, Garcia-Herrero S, Meseguer M. Assessment of sperm using mRNA microarray technology. Fertil Steril. 2013;99(4):1008-22.

Issa NT, Byers SW, Dakshanamurthy S. Big data: the next frontier for innovation in therapeutics and healthcare. Expert Rev Clin Pharmacol. 2014;7(3):293-8.

Martinelli L, Busatta L, Galvagni L, Piciocchi C. Social egg freezing: a reproductive chance or smoke and mirrors? Croat Med J. 2015;56(4):387-91.

Meseguer M, Kruhne U, Laursen S. Full in vitro fertilization laboratory mechanization: toward robotic assisted reproduction? Fertil Steril. 2012;97(6):1277-86.

National Research Council (Washington DC, USA). Division on Earth and Life Studies. Committee on Key Challenge Areas for Convergence and Health Board on Life Sciences. Convergence: facilitating transdisciplinary integration of life sciences, physical sciences, engineering, and beyond. USA: National Academies Press; 1 online resource (151 pp.); 2014.

Niederberger C, Pellicer A, Cohen J, Gardner DK, Palermo GD, O'Neill CL, et al. Forty years of IVF. Fertil Steril. 2018;110(2): 185-324 e5. 
Normile D. Shock greets claim of CRISPR-edited babies. Science. 2018;362(6418):978-9.

Ristevski B, Chen M. Big data analytics in medicine and healthcare. J Integr Bioinform. 2018;15(3):pii: /j/jib.2018.15.issue-3/jib-20170030/jib-2017-0030.xml. doi: 10.1515/jib-2017-0030.

Rosenbluth EM, Shelton DN, Wells LM, Sparks AE, Van Voorhis BJ. Human embryos secrete microRNAs into culture media - a potential biomarker for implantation. Fertil Steril. 2014;101(5): 1493-500.

Ruiz-Alonso M, Blesa D, Diaz-Gimeno P, Gomez E, FernandezSanchez M, Carranza F, et al. The endometrial receptivity array for diagnosis and personalized embryo transfer as a treatment for patients with repeated implantation failure. Fertil Steril. 2013;100(3):818-24.

Sanchez T, Seidler EA, Gardner DK, Needleman D, Sakkas D. Will noninvasive methods surpass invasive for assessing gametes and embryos? Fertil Steril. 2017;108(5):730-7.

Simón C, Giudice L. The Endometrial Factor: A Reproductive Precision Medicine Approach. Boca Raton, FL: CRC Press/Taylor \& Francis Group; 2017. xi, 271 pp.

Topol EJ. The Topol Review - Preparing the healthcare workforce to deliver the digital future: an independent report on behalf of the Secretary of State for Health and Social Care. National Health Service (NHS), February 2019. https://topol.hee.nhs.uk
Topol EJ. Acute Coronary Syndromes. New York: Marcel Dekker, Inc.; 1998. x, 628 pp.

Upadhyay RD, Balasinor NH, Kumar AV, Sachdeva G, Parte P, Dumasia K. Proteomics in reproductive biology: beacon for unraveling the molecular complexities. Biochim Biophys Acta. 2013;1834(1):8-15.

Wiweko B, Prawesti DM, Hestiantoro A, Sumapraja K, Natadisastra M, Baziad A. Chronological age vs biological age: an age-related normogram for antral follicle count, FSH and anti-Mullerian hormone. J Assist Reprod Genet. 2013;30(12):1563-7.

Wiweko B, Utami P. Predictive value of sperm deoxyribonucleic acid (DNA) fragmentation index in male infertility. Basic Clin Androl. 2017;27:1.

Wiweko B, Wibawa YS, Febri RR, Mutia K, et al. Indonesian Kalkulator of Oocytes (IKO): a validation study to establish smart application to determine biological age. AIP Conf Proc. 2019;2092:040006.

Woods DC, Tilly JL. Autologous Germline Mitochondrial Energy Transfer (AUGMENT) in Human Assisted Reproduction. Semin Reprod Med. 2015;33(6):410-21. 